Alkenone-based temperature patterns along the eastern

South Pacific

J. A. Placencia et al.

\title{
Alkenone-based temperature patterns along the eastern South Pacific Coastal Ocean: the effect of upwelling and advection on the sedimentary alkenone unsaturation-index $\left(U_{37}^{K^{\prime}}\right)$
}

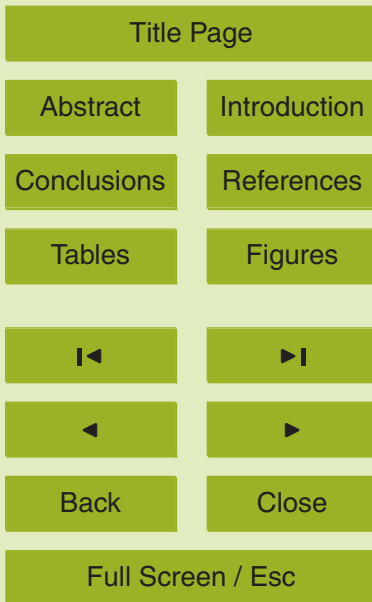

J. A. Placencia ${ }^{1,2,3}$, J. Garcés-Vargas ${ }^{4}$, C. B. Lange ${ }^{2}$, and D. Hebbeln ${ }^{5}$

${ }^{1}$ Graduate Program in Oceanography, Department of Oceanography, University of Concepción, Concepción, Chile

${ }^{2}$ Department of Oceanography and Center for Oceanographic Research in the eastern South Pacific (FONDAP-COPAS), University of Concepción, Concepción, Chile

${ }^{3}$ Department of Environmental Chemistry, Faculty of Sciences, Universidad Católica de la Santísima Concepción, Concepción, Chile

Printer-friendly Version

Interactive Discussion 
4 Instituto de Biología Marina, Universidad Austral de Chile, Valdivia, Chile

${ }^{5}$ MARUM Center for Marine Environmental Sciences, Bremen University, Bremen, Germany

Received: 4 January 2010 - Accepted: 6 January 2010 - Published: 21 January 2010

Correspondence to: J. A. Placencia (jplacenc@udec.cl)

Published by Copernicus Publications on behalf of the European Geosciences Union.
BGD

7, 545-564, 2010

Alkenone-based temperature patterns along the eastern South Pacific

J. A. Placencia et al.

Title Page

Abstract Introduction

Conclusions References

Tables Figures

14 $>$ I

4

Back

Close

Full Screen / Esc

Printer-friendly Version

Interactive Discussion 


\section{Abstract}

We report that the sedimentary record of alkenone unsaturation-index $\left(U_{37}^{K^{\prime}}\right)$ in the eastern South Pacific displays a wide range of temperatures, in response to sea surface temperature (SST), as well as nutrient concentrations. The $U_{37}^{K^{\prime}}$ inshore-offshore trend 5 shows low-correlation with SSTs at many transitional sites (50-200 km offshore), and in one oligotrophic coastal site $\left(\sim 20^{\circ} \mathrm{S}\right)$. In contrast, in open-ocean sites SSTs play the expected dominant role. The latitudinal trend shows that nitrate, phosphate and/or temperature affect distinctively the $U_{37}^{K^{\prime}}$, suggesting progressive high-impacts in areas with permanent nutrient-stress conditions $\left(\sim 20^{\circ} \mathrm{S}\right)$, which is consistent with previous experiments. In contrast, this impact is slightly and not observable in transitional and open-ocean areas, respectively, where the coupling between offshore propagation of mesoscale eddies and upwelling filaments supply additional chlorophyll/nutrient. This study is a first field approximation to the impacts of thermal/non-thermal factors over the unsaturation-index in eastern Boundary Current systems, which would help in future temperature reconstructions.

\section{Introduction}

The alkenone unsaturation-index $\left(U_{37}^{K^{\prime}}\right)$ is now accepted as an appropriate proxy of sea surface temperature (SST) and alkenone-integrated production temperature (alkenone-IPT) (Conte et al., 2006) over a wide range of latitudes. The statisticallybased core-top calibration for the global ocean $\left(60^{\circ} \mathrm{S}-60^{\circ} \mathrm{N}\right.$ ) (Müller et al., 1998) closely matches the original laboratory calibration for a single-strain 55a of Emiliania huxleyi grown in batch culture (e.g., Prahl et al., 1988), even though significant scatter in the overall dataset exists (e.g., Conte et al., 2006). Conte et al. (2006) concluded that the deviation of alkenone-IPT from Levitus estimates was best explained by a com-
BGD

7, 545-564, 2010

\section{Alkenone-based temperature patterns along the eastern South Pacific}

J. A. Placencia et al.

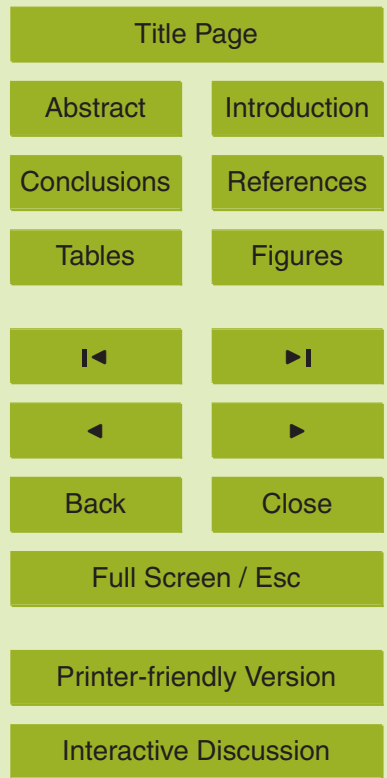


On the other hand, it has been suggested that the degree of variability in $U_{37}^{K^{\prime}}$ for a given mean annual SST (maSST) could be caused by non-thermal physiological growth factors such as nutrient- and light-stress which may have an effect on the accuracy of paleotemperature estimates based on $U_{37}^{K^{\prime}}$ determinations (e.g., Prahl et al., 2006).

$5 \quad$ Given the potential for non-thermal physiological effects on alkenone biosynthesis (e.g., Prahl et al., 2006) and for biosynthetic differences within a given genotype of alkenone-producing Haptophytes (Rontani et al., 2006), $U_{37}^{K^{\prime}}$ recorded in sediments from ocean margins and, in particular, from coastal upwelling areas might show temperature values inconsistent with global ocean core-top calibrations. Furthermore, the 10 U $U_{37}^{K^{\prime}}$-signal may also be associated with different nutrient supply pathways produced by horizontal advection and/or vertical upwelling of nutrients due to cyclonic/anticyclonic mesoscale eddies and/or mode-water eddies (e.g., McGillicuddy et al., 2007).

By extrapolating information from laboratory experiments and some field studies we can infer that the $U_{37}^{K^{\prime}}$ may vary due to nutrient variability along the Peru-Chile margin, and from coastal to oceanic environments. This aspect motivated our selection of the Peru-Chile margin as a natural setting to explore the potential deviations that the $U_{37}^{K^{\prime}}$ may undergo due to the drastically fluctuating environmental conditions of this ecosystem (i.e., upwelling, filaments and eddies) (e.g., Correa-Ramirez et al., 2007).

Data from Eastern Boundary Upwelling Ecosystems are still insufficient, and the potential effects of nutrient variability derived from coastal upwelling and/or advection processes on the $U_{37}^{K^{\prime}}$-signal exported to the sedimentary record is largely unknown. Our results will help in future interpretations of temperature reconstructions in these regions. Moreover, our findings can provide at least partial explanation for scatters and inconsistencies observed between $U_{37}^{K^{\prime}}$ measurements and maSST in the Peru-Chile
BGD

$7,545-564,2010$

\section{Alkenone-based temperature patterns along the eastern South Pacific}

J. A. Placencia et al.

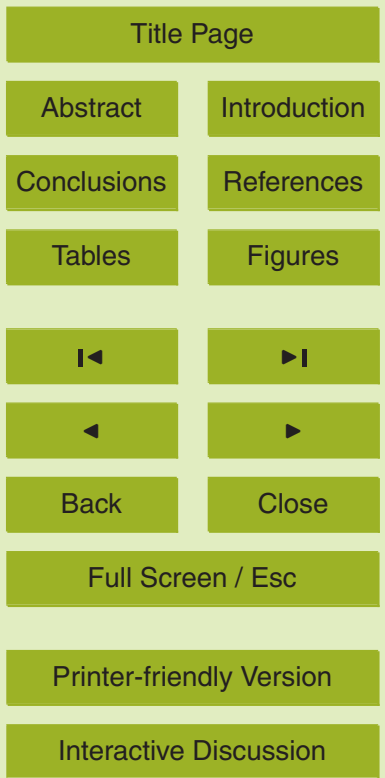




\section{Methods}

Alkenone analysis was performed on the uppermost centimeter of sediment cores $(n=39)$ collected with Multi corer and Box corer during several cruises along the PeruChile margin. 5-6 g of freeze-dried sediments samples were extracted by sonication 5 with $25 \mathrm{~mL}$ of $\mathrm{MeOH}$ for $30 \mathrm{~min}$ at room temperature (x2) and centrifuged at $2000 \mathrm{rpm}$ for $3 \mathrm{~min}$. A recovery standard $\left(\mathrm{C}_{35}\right.$ straight chain ketone) was added to the samples before the extraction. The resultant lipid residue was transferred to a separatory funnel and $25 \mathrm{~mL}$ of a mixture of DCM/MeOH was added (3:1) (x3). The extracts were combined and separated with hexane $60 \mathrm{~mL}(\mathrm{x} 2)$ and $40 \mathrm{~mL}(\mathrm{x} 1)$. The hexane fraction was 10 washed first with $40 \mathrm{~mL}$ of Milli-Q water (washed w/DCM) and later with a solution of $5 \% \mathrm{NaCl}$. The organic phase was dried overnight with $\mathrm{Na}_{2} \mathrm{SO}_{4}$ anhydrous, and concentrated on a rotavapor. The concentrate was subjected to column cromatography with $7 \mathrm{~g}$ of $5 \%$ deactivated silica-gel, to separate lipid functional groups of total extract (Prahl et al., 1989). Different fractions were concentrated on a rotavapor and dried with $15 \mathrm{~N}_{2}$ within a GC vial (with DCM). Fractions were diluted with iso-octane and an internal standard ( $5 \alpha$-cholestane) was added.

The different fractions were analyzed in a GC SHIMADZU, equipped with a capillary column (RTX-SMS, $0.25 \mu \mathrm{m}$ d.f., $0.32 \mathrm{~mm}$ i.d. $\times 30 \mathrm{~m}$ of longitude, RESTEK) and a flame ionization detector (FID). The separation of compounds was development with hydrogen as carrier gas ( 10 psig column head pressure, $6.37 \mathrm{~mL} / \mathrm{min}$ column flow). The temperature regime for gas chromatography was as follows: initial column temperature at $50^{\circ} \mathrm{C}$ for $1 \mathrm{~min}$, increased to $120^{\circ} \mathrm{C}$ at $30^{\circ} \mathrm{C} / \mathrm{min}$, increased to $300^{\circ} \mathrm{C}$ at $6{ }^{\circ} \mathrm{C} / \mathrm{min}$, isothermal at $300^{\circ} \mathrm{C} / 48 \mathrm{~min}$, total time $81.3 \mathrm{~min}$.

$U_{37}^{K^{\prime}}$-index calculations were conducted according to Prahl and Wakeham (1987), 25 and $U_{37}^{K^{\prime}}$ values were converted to alkenone-based temperature $\left(U_{37}^{K^{\prime}}\right.$-SST) using the equation of Prahl et al. (1988), i.e., $U_{37}^{K^{\prime}}=0.034 T+0.039$ (1), where $T$ =temperature $\left({ }^{\circ} \mathrm{C}\right)$. Analytical accuracy was $\pm 0.2^{\circ} \mathrm{C}$.

We also included 44 data points previously published for the area; the complete set of
BGD

$7,545-564,2010$

\section{Alkenone-based temperature patterns along the eastern South Pacific}

J. A. Placencia et al.

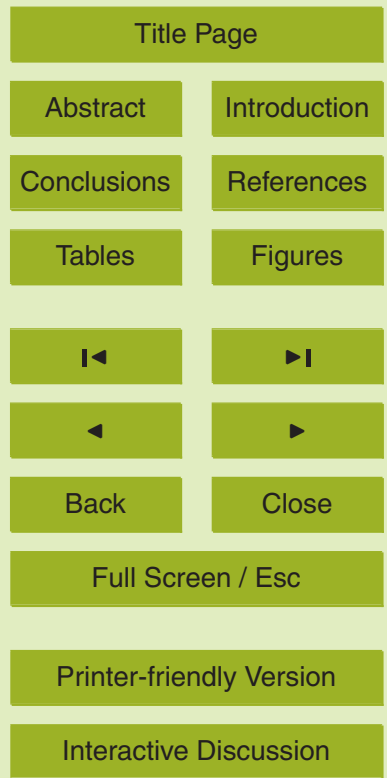


samples $(n=83)$ covered the area between $0^{\circ}$ and $50^{\circ} \mathrm{S}$ (see data supplement: http: //www.biogeosciences-discuss.net/7/545/2010/bgd-7-545-2010-supplement.pdf). Although the locations studied here display differences in sedimentation rates and bioturbation depths (Muñoz et al., 2004) and may cover the last several hundred years of 5 deposition (e.g., Prahl et al., 2006), they are all of Holocene age, and thus are considered suitable for the objectives of this study. Chlorophyll-a climatology data from the SeaWiFS sensor was derived by time-series files, from September 1997 to August 2007. Maximum/minimum values of Chlorophyll-a concentration were identified for each site along the Peru-Chile margin. The maSSTs and nutrients datasets were 10 extracted from the NOAA World Ocean Atlas 2001 (Conkright et al., 2002). The SeaWiFS data used in this study was acquired using the GES-DISC Interactive Online Visualization ANd aNalysis Infrastructure (Giovanni) as part of the NASA's Goddard Earth Sciences (GES) Data and Information Services Center (DISC) (Available at: http://reason.gsfc.nasa.Gov/OPS/Giovanni/ocean.seawifs.shtml/, 2008).

\section{Results}

\subsection{Coastal upwelling to open ocean areas overview}

The $U_{37}^{K^{\prime}}$-maSST relationship for the Peru-Chile margin displays a significant linear regression, but a relatively low-coefficient $\left(r^{2}=0.66\right)$. Moreover, the $U_{37}^{K^{\prime}} / \mathrm{SST}$ does not change seasonally, and is not significantly different from the annual temperatures (summer: $r^{2}=0.70$; winter: $r^{2}=0.71$ ), and the coefficients are also low (Table 1). Thus, $U_{37}^{K^{\prime}}$ in our study area would record the maSST. The lower regression coefficients found for the study area would be explained by implication of coastal sites that are affected by upwelling-associated nutrient injection/consumption. Simple-linear regressions were developed between the $U_{37}^{K^{\prime}}$ vs. maSST, nitrate, and phosphate concentrations for the
BGD

$7,545-564,2010$

\section{Alkenone-based temperature patterns along the eastern South Pacific}

J. A. Placencia et al.

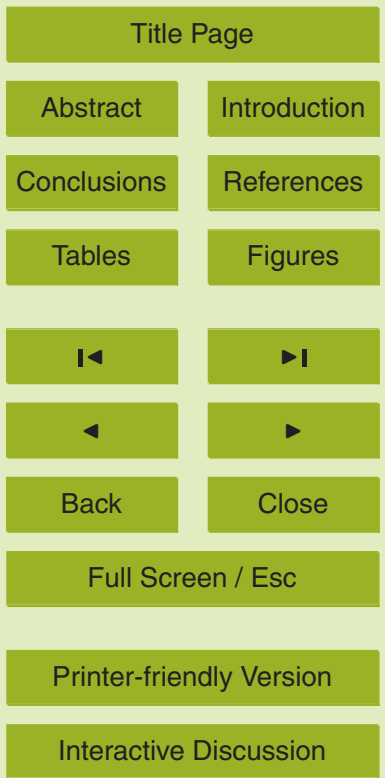


with the original laboratory calibration (Fig. 1) (Prahl et al., 1988). A "poor" correspondence between $U_{37}^{K^{\prime}}$ and maSST within the coastal upwelling $\left(r^{2}=0.18\right)$ and transition areas $\left(r^{2}=0.37\right)$ was observed (Fig. 1). Moreover, regression lines from upwelling and transition areas do not exhibit a close relationship with the original laboratory calibra-

5 tion. On the other hand, only the sites within the coastal upwelling boundary displayed significant correlations between the $U_{37}^{K^{\prime}}$ and nitrate and phosphate (Fig. 1). In contrast, the high- $U_{37}^{K^{\prime}} /$ maSST coefficient in open-ocean areas is consistent with the regional SST-trend and E. huxleyi strain 55a culture experiment (Fig. 1).

\subsection{Potential impact of non-thermal factors on the $U_{37}^{K^{\prime}}$}

10 In order to evaluate the impact of non-thermal factors on the $U_{37}^{K^{\prime}}$, we calculated the residuals of temperatures for each data point (Fig. 2a). They display a wide range of temperature differences for the study area (between $2{ }^{\circ} \mathrm{C}$ and $-6{ }^{\circ} \mathrm{C}$, with one data point at $-7.9^{\circ} \mathrm{C}$ ), and a standard deviation of $\pm 2.3^{\circ} \mathrm{C}$ (Fig. 2a). Our $\pm 2.3^{\circ} \mathrm{C}$ standard deviation is $0.8^{\circ} \mathrm{C}$ higher than the one estimated for the global ocean calibration from

15 Müller et al. (1998) $\left( \pm 1.5^{\circ} \mathrm{C}, 60^{\circ} \mathrm{S}-60^{\circ} \mathrm{N}\right.$, see Table 1$)$, probably due to the several data points with cold $U_{37^{\prime}}^{K^{\prime}}$-SST in our study area (Fig. 2a).

Figure 3 displays the latitudinal distribution of $U_{37}^{K^{\prime}}$-SST from surface sediments along the Peru-Chile margin, and their relationship with the maSST, nitrate and phosphate, chlorophyll-a concentration, and the upwelling-index. The latter shows prominent max20 ima at $15^{\circ} \mathrm{S}$ and $30^{\circ} \mathrm{S}$, and minimum values around $20^{\circ} \mathrm{S}$; southward of $40^{\circ} \mathrm{S}$ is a non-upwelling system (Fig. 3b). Seasonal differences in the upwelling-index are only important off central/southern Chile $\left(\sim 34^{\circ}-36^{\circ} \mathrm{S}\right)$.

Around $25 \%$ of the total samples collected in the coastal upwelling and transition areas off Peru $\left(\sim 12^{\circ} \mathrm{S}\right)$ and central/southern Chile $\left(\sim 36^{\circ} \mathrm{S}\right.$ and $\left.\sim 40^{\circ} \mathrm{S}\right)$ lie within the 25 standard deviation (black rectangles in Fig. 3a). Coldest $U_{37^{\prime}}^{K^{\prime}}$-SSTs were detected off northern Chile mainly in the coastal upwelling zone at $\sim 20^{\circ} \mathrm{S}$, the transition area at

\section{Alkenone-based temperature patterns along the eastern South Pacific}

J. A. Placencia et al.

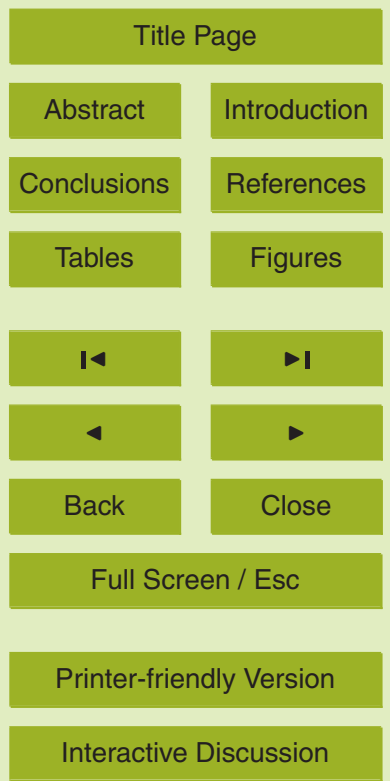


$\sim 28^{\circ} \mathrm{S}$, and off central Chile $\left(\sim 34^{\circ} \mathrm{S}\right)$. Together, these sites comprise $20 \%$ of the total (Fig. 3a). Non-linearity in the $U_{37}^{K^{\prime}}$-SST/maSST relationship is clearly present here (Fig. 3a), and thus this scatter could reflect an influence of non-temperature related factors on the $U_{37}^{K^{\prime}}$.

$5 \quad$ Within the area where the coldest $U_{37}^{K^{\prime}}$-SST were found, the nitrate concentrations were lowest between $20^{\circ}$ and $24^{\circ} \mathrm{S}(<1 \mu \mathrm{M})$, and increased toward the south $(\sim 5 \mu \mathrm{M}$ at $\sim 34^{\circ} \mathrm{S}$ ). Phosphate concentrations ranged between $\sim 0.5$ and $\sim 0.7 \mu \mathrm{M}$ in this area (Fig. 3a). The area between $20^{\circ} \mathrm{S}$ and $24^{\circ} \mathrm{S}$ could be considered as a potential lownutrient/low-chlorophyll-a area (LNLC, Fig. 3a).

10 In the coastal upwelling area, samples with lowest $U_{37}^{K^{\prime}}$ /highest maSST (between $20^{\circ} \mathrm{C}$ and $22^{\circ} \mathrm{C}$, dashed area in Fig. 1) exhibit a close relationship with low- $U_{37}^{K^{\prime}} /$ lownitrate (between 0 and $2 \mu \mathrm{M}$, Fig. 1). Likewise, the same samples exhibit a similar relationship with low- $U_{37}^{K^{\prime}} /$ low-phosphate (Fig. 1). This finding would suggest that when nitrate and phosphate are low in the seawater they potentially control the $U_{37}^{K^{\prime}}$ rather 15 than temperature, a scenario that would be possible in areas where upwelling events are permanent and nutrient-uptake by phytoplankton occurs year-round (e.g., northern Chile).

On the other hand, the samples located between $\sim 30^{\circ}$ and $\sim 34^{\circ} \mathrm{S}$ (Fig. 3a) show a mixed signal potentially derived from significant changes of nutrient input between summer and winter. In this area, the main nutrient input by upwelling events occurs during summer, while winter is a non-upwelling period (Fig. 3b). No-additional contribution of nutrients from riverine sources is expected since large rivers are only found at $36^{\circ} \mathrm{S}$ and southward (Fig. 3b). However, as mentioned above (see Introduction) additional contribution of nutrients/chlorophyll-a, as well as salt and heat, may have an influence in the region due to offshore transport by mesoscale eddies.

\section{BGD}

$7,545-564,2010$

\section{Alkenone-based temperature patterns along the eastern South Pacific}

J. A. Placencia et al.

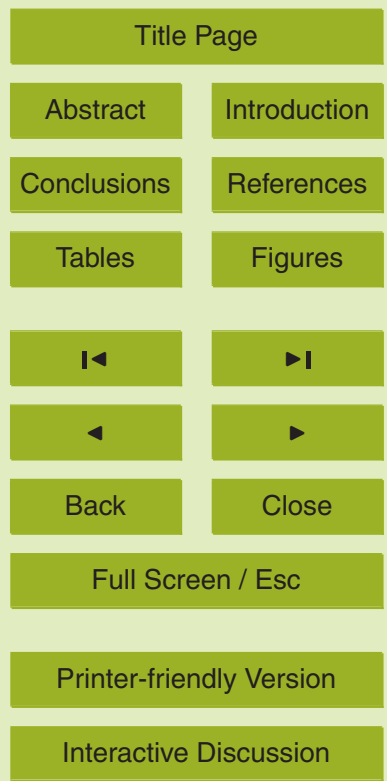




\section{Discussion}

\subsection{Possible factors controlling the alkenone unsaturation-index signal in sur- face sediments from coastal upwelling to open-ocean areas}

The overall trend of increasing $U_{37}^{K^{\prime}}$ /nutrient regressions from the open-ocean to the 5 coast suggests a nutrient effect on the $U_{37}^{K^{\prime}}$ in coastal upwelling areas (Fig. 1). In contrast, the effect of temperature on the $U_{37}^{K^{\prime}}$ increases offshore (Fig. 1), probably masking the nutrient effect toward open-ocean, and showing that the index faithfully records water temperatures in oceanic areas, as has been shown previously (Müller et al., 1998).

10 From culture experiments Prahl et al. (2003) observed that a decrease in nitrate (from $\sim 20$ to $0 \mu \mathrm{M}$ ) and phosphate (from $\sim 0.5$ to $0.1 \mu \mathrm{M}$ ) concentrations induces a change in the $U_{37}^{K^{\prime}}$ from 0.5 to 0.41 , and suggested that the effect of nutrient-stress in the seawater changes the $U_{37}^{K^{\prime}}$-SST by $\sim 3^{\circ} \mathrm{C}$. Thus, nutrient-stress condition alone could cause a decrease on $U_{37}^{K^{\prime}}$, producing unusually cold-temperature estimates. Therefore, we may assume that the atypical cold-residual temperatures found in the Peru-Chile upwelling system (Fig. 2a) could mirror the impacts derived from nutrient-stress conditions. Our data can be compared with those previously published for other coastal upwelling systems (e.g., Müller et al., 1998) where similar anomalously low- $U_{37}^{K^{\prime}}-S S T$ have been observed, with residual values that range from $-1.5^{\circ}$ to $-5.5^{\circ} \mathrm{C}$ for the California margin, and from $-1.0^{\circ}$ to $-3.0^{\circ} \mathrm{C}$ for the Benguela-Angola margin (Fig. $2 \mathrm{~b}$ and $\mathrm{c}$ ). In these areas, the low-values also coincide with low-nitrate concentrations $(<2 \mu \mathrm{M})$ (Conkright et al., 2002).

Lowest temperatures found in the near coastal area off northern Chile $\left(\sim 20^{\circ} \mathrm{S}\right)$ may well be related to nutrient-stress and could be explained by both the year-round low-

volume of upwelled nutrient-rich Equatorial Subsurface Waters (ESSW, see upwellingindex in Fig. 3b) limited to the nearshore area $(<60 \mathrm{~km})$ (e.g., Strub et al., 1998); and

BGD

7, 545-564, 2010

Alkenone-based temperature patterns along the eastern South Pacific

J. A. Placencia et al.

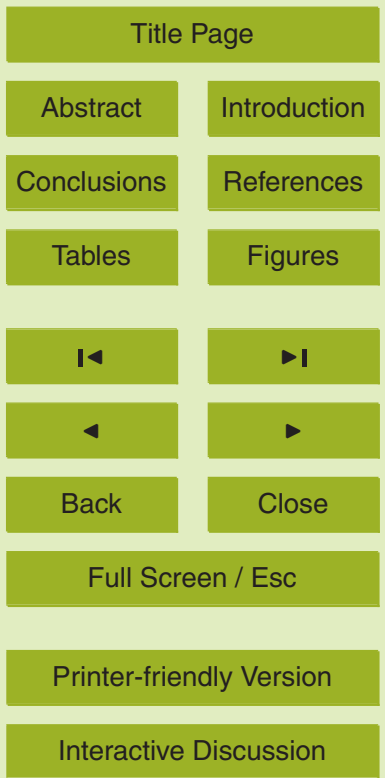


a complete nutrient utilization by phytoplankton which produces a pattern of very lowsurface nitrate $(<2 \mu \mathrm{M})$ and chlorophyll-a $\left(<1 \mathrm{mg} \mathrm{m}^{-3}\right.$, LNLC, Fig. 3a). Intense and brief summer wind-driven upwelling has been described for this area which strength could be reduced by semi-permanent shoreward flow of warmer-waters (e.g., Strub et al., 5 1998). All these characteristics may impose a year-round nutrient-stress environment for coccolithophorids. In fact, the critical nitrate concentration below which alkenone producers experience physiological stress is $4 \mu \mathrm{M}$ and $0.2 \mu \mathrm{M}$ of phosphate (Prahl et al., 2003).

On the other hand, previous studies support our finding that the low-temperatures 10 derived from marine sediments are shaped by an alkenone-signal from a water column permanently depleted in nutrients. De Pol-Holz et al. (2009) documented high- $\delta{ }^{15} \mathrm{~N}$ values $(\sim 15 \%$ o) in the coastal surface sediments off northern Chile, indicating that the sedimentary record represents either a progressive consumption of nitrate where the nitrate supply is small, or an active denitrification in the water column. Thus, a $U_{37}^{K^{\prime}}$ 15 from nutrient-depleted areas would derive from a physiological response of Haptophyte cells to nutrient variability, but not necessarily to changes in water column temperature. Alternatively, this phenomenon can be also attributed to either alkenone-production occurs deeper down in the water column, probably associated with a deeper chlorophyll-a maximum at the thermocline depth (e.g., Harada et al., 2006).

20 On the other hand, one could infer that the coldest $U_{37}^{K^{\prime}}$ found in marine sediments from northern Chile reflect temperatures from seasonal strong-upwelling events rather than the maSSTs. This possibility is rather unlikely since the annual variability of SST in this area ranges between $\sim 16^{\circ}$ and $\sim 23^{\circ} \mathrm{C}$ whereas the $U_{37^{\prime}}^{K^{\prime}}$-SSTs are significantly lower (Fig. 3a). However, as the upwelling strength varies inter-annually, we note that 25 the abnormally cold- $U_{37}^{K^{\prime}}$ sedimentary record also represent temperatures during extreme upwelling periods, e.g., strong La Niña years.

Our results reveal that the intensity of nutrient impact on the $U_{37}^{K^{\prime}}$-SST signature decreases significantly southward (Fig. 1a). In fact, low $-\delta^{15} \mathrm{~N}$ values $(\sim 10 \%)$ in the
BGD

$7,545-564,2010$

\section{Alkenone-based temperature patterns along the eastern South Pacific}

J. A. Placencia et al.

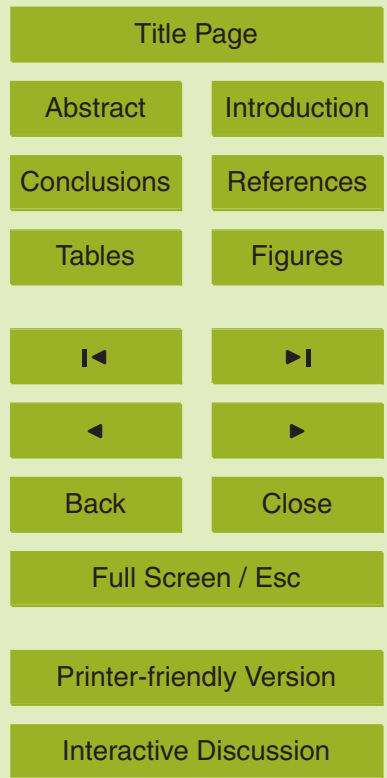


coastal surface sediments south of $36^{\circ} \mathrm{S}$ indicate higher nutrient availability (e.g., De Pol-Holz et al., 2009). Maximum values of chlorophyll-a $\left(\sim 10-12 \mathrm{mg} \mathrm{m}^{-3}\right)$, annual nitrate $(\sim 5 \mu \mathrm{M})$, and phosphate $(\sim 0.5-1.0 \mu \mathrm{M})$ concentrations are observed off $36^{\circ}$ and $40^{\circ} \mathrm{S}$ (Fig. 3a). Upwelling of the nutrient-rich ESSW and continuous riverine input of nutrients (Fig. 3b), and perhaps high-iron concentration, induce high-nutrient concentrations off central/southern Chile almost year-round, and nutrient-depleted conditions only occur sporadically (Gonzalez et al., 2007). Alternatively, as the upwelling-index displays negative values (Fig. 1b), an additional input of nutrients from the south transported by the northward extension of the Antarctic Circumpolar Current has been suggested by other studies (e.g., Mohtadi et al., 2005). In summary, our results indicate that south of $\sim 36^{\circ} S$ the $U_{37}^{K^{\prime}}$ is mainly controlled by temperature rather than nutrients.

This is also the case for the samples collected off Peru $\left(\sim 12^{\circ} \mathrm{S}\right.$, Fig. 3a), since surface mean annual nitrate and phosphate concentrations and the upwelling-index display maximum values (Fig. 3) suggestive of high-nutrient availability. Moreover, low${ }_{15} \delta{ }^{15} \mathrm{~N}$ values (<10\%) reported for the coastal surface sediments off Peru would suggest a signal derived from an enriched nutrient pool of the upwelled waters (Niggemann, 2005). If our assumptions are correct, then samples from off Peru and central/southern Chile display $U_{37}^{K^{\prime}}$-SST reflecting the actual water column temperatures, in contrast to those samples beneath permanent low-nutrient conditions off northern Chile.

The oceanic sites along the study area exhibit low-nitrate and -phosphate conditions with mean annual values of $\sim 0-5 \mu \mathrm{M}$ and $\sim 0.5-0.6 \mu \mathrm{M}$, respectively. Anomalously cold- $U_{37}^{K^{\prime}}$-SST, as a result of nutrient-stress, was not observed in these areas (Fig. 3a). Furthermore, the oceanic sites exhibited the best $U_{37}^{K^{\prime}} /$ maSST regression, discarding the nutrient effect on the $U_{37}^{K^{\prime}}$ (Fig. 1). Although the annual and seasonal nu- trient dataset (Conkright et al., 2002) do not show additional input of nutrients offshore, this could occur by physical mechanisms thus influencing the distribution of biological components in the pelagic environment, mainly through the cross-shelf transport of plankton and the exchange of particulate and dissolved organic and inorganic matter
BGD

$7,545-564,2010$

\section{Alkenone-based temperature patterns along the eastern South Pacific}

J. A. Placencia et al.

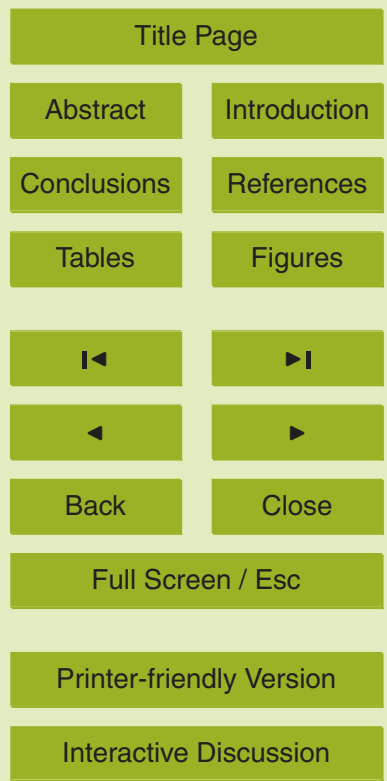


between the coastal and the oligotrophic open-ocean areas (e.g., Alvarez-Salgado et al., 2007). The potential accumulation of organic material at the surface waters would favor the growth of bacteria, and hence nutrient regeneration, and, in turn, phytoplankton growth and chlorophyll-a increase in oceanic areas (Dandonneau et al., 2003). On 5 the other hand, the vertical nutrient fluxes into the euphotic zone associated with cyclonic eddies, could be an alternative source of nutrients to the oligotrophic open-ocean waters, which should be sufficient to support the new primary production in these areas (e.g., McGillicuddy et al., 2007). The oceanic core-sites around $20^{\circ} \mathrm{S}$ (Fig. 3a) could be recording a $U_{37}^{K^{\prime}}$-signal derived from potentially healthy cell conditions, due to enough nutrient supply by cyclonic eddies transported offshore. In fact, eddies display the highest kinetic energy values here $\left(>100 \mathrm{~cm}^{2} \mathrm{~s}^{-2}\right.$, Fig. 3a) (Correa-Ramirez et al., 2007).

Cold-coastal filaments and mesoscale eddies have been described off northern and central Chile (e.g., Correa-Ramirez et al., 2007). The surface transport/accumulation of 15 organic material to the oceanic oligotrophic areas during summer/winter suggests that the alkenone signature found in surface sediments from oceanic areas reflects both a coupling between nutrient regeneration process by accumulation of allochtonous organic material during winter (Correa-Ramirez et al., 2007), vertical nutrient-pumping from cyclonic eddies (e.g., McGillicuddy et al., 2007), and seaward nutrient-rich up20 welling filaments during summer (e.g., Correa-Ramirez et al., 2007). All these mechanisms provide enough nutrients to alkenone-producing algae into oceanic areas, and as a result, the $U_{37}^{K^{\prime}}$ is dependent on the temperature regimes solely (Fig. 1). Although the nutrient vertical and horizontal advection could inflict physiological-stress on the alkenone-producing algae (i.e., alkenone/alkenoate ratio) (Prahl et al., 2006), this effect 25 was not observed in the $U_{37}^{K^{\prime}}$-SSTs from open-ocean (Fig. 3a). Alternatively, different alkenone-producing Haptophytes species may have different physiological responses, and consequently different effect on the $U_{37}^{K^{\prime}}$-signal (Rontani et al., 2006).

For the transitional area (50-200 km offshore), the pattern of the $U_{37}^{K^{\prime}}$ /nutrient re-
BGD

$7,545-564,2010$

\section{Alkenone-based temperature patterns along the eastern South Pacific}

J. A. Placencia et al.

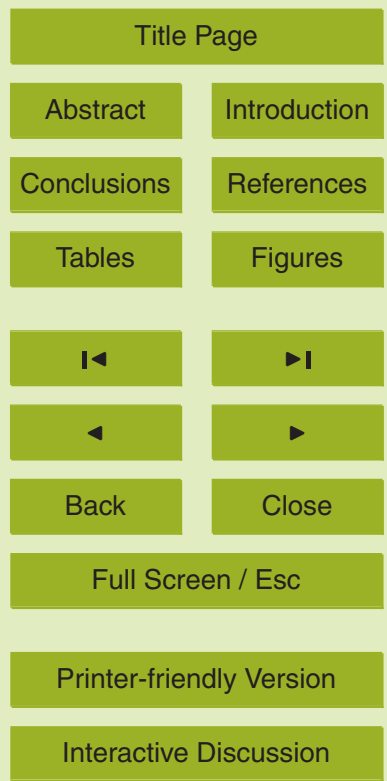


gressions (Fig. 1) may represent a signal of temporary advective processes offshore from coastal sites, as follows. Cyclonic/anticyclonic eddies generated along the continental margin drift in a general westward direction through the transitional area off central Chile $\left(30^{\circ}-36^{\circ} \mathrm{S}\right)$, transporting high-chlorophyll-nutrient levels to $\sim 500 \mathrm{~km}$ off-

5 shore, especially during winter (e.g., Correa-Ramirez et al., 2007). These features are stable for several months ( $\sim 6$ months), and could be a potential transport mechanism of cold-water anomalies from the coastal upwelling areas.

On the other hand, for the transition samples located between $27^{\circ} \mathrm{S}$ and $32^{\circ} \mathrm{S}$, with high-nutrient/low-chlorophyll-a conditions (HNLC, Fig. 3a), micronutrients such as iron 10 is the most important limiting factor for the carbon pump (Torres and Ampuero, 2009). Here, riverine discharges are negligible (Fig. 3b). Thus, low-temperatures estimated in this area (Fig. 3a) may be a direct effect of iron-limitation on nutrient uptake processes.

This study is a first field approximation of the possible impacts of thermal/non-thermal factors on the alkenone unsaturation-index in one Eastern Boundary Current System 15 (Peru-Chile), and raises the importance of onshore-offshore advective processes which could be helpful for the interpretation of paleorecords.

\section{Concluding remarks}

The sedimentary $U_{37}^{K^{\prime}}$ record along the Peru-Chile margin is a signal derived from ecological and/or physiological changes, as a result of the systematic changes in seawater 20 temperature, nutrient availability conditions, or a combination of both. These changes can be mainly explained by upwelling events and/or offshore transport of heat and highchlorophyll-a/nutrient concentration by mesoscale eddies. Lowest $U_{37}^{K^{\prime}}$-temperatures in the near coastal area off northern Chile (e.g., $\sim 20^{\circ} \mathrm{S}$ ), are shaped by an alkenonesignal from a water column permanently depleted in nutrients. Alternatively, these temperatures also reflect strongest upwelling events, and/or a cold-signal derived from the alkenone-production at the thermocline depth. In contrast, the $U_{37}^{K^{\prime}}$-temperatures at

\section{BGD}

$7,545-564,2010$

\section{Alkenone-based temperature patterns along the eastern South Pacific}

J. A. Placencia et al.

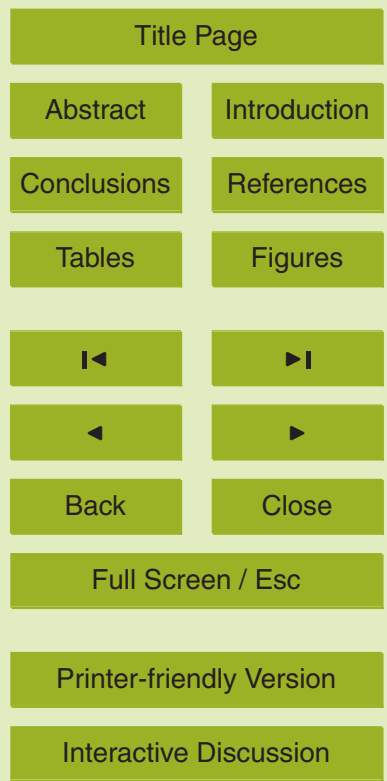


$\sim 20^{\circ} \mathrm{S}$ in the open-ocean area describe additional nutrient supply by eddies mechanisms. Moreover, the coupling between the offshore propagation of mesoscale eddies and upwelling filaments explain the $U_{37}^{K^{\prime}}$ in agreement with maSST found in the openocean sites, suggesting that the temperature is the controlling factor for $U_{37}^{K^{\prime}}$ in these 5 areas. In fact, through the transitional area, the effect of temperature on the $U_{37}^{K^{\prime}}$ increases offshore, while the nutrient effect disappears, as result of offshore advection of mesoscale eddies.

Acknowledgements. This work was funded by the FONDAP-COPAS Center (Grant No. 150100007). J. A. P. was supported by scholarships: Grant MECESUP/UCO-0002, the 10 Graduate School at University of Concepcion, the UDEC-FA-WHOI program, and the European Association of Organic Geochemists (EAOG). We acknowledge comments and suggestions by M. Mohtadi, and F. Prahl for his comments in the early versions of this manuscript.

\section{References}

Álvarez-Salgado, X. A., Arístegui, J., Barton, E. D., and Hansell, D. A.: Contribution of upwelling filaments to offshore carbon export in the subtropical Northeast Atlantic Ocean, Limnol. Oceanogr., 52, 1287-1292, 2007.

Correa-Ramirez, M. A., Hormazábal, S., and Yuras, G.: Mesoscale eddies and high chlorophyll concentrations off central Chile $\left(29^{\circ}-39^{\circ} \mathrm{S}\right)$. Geophys. Res. Lett., 34, L12604, doi:10.1029/2007GL029541, 2007.

20 Conkright, M. E., Locarnini, R. A., Garcia, H. E., O'Brien, T. D., Boyer, T. P., Stephens, C., and Antonov, J. I.: World Ocean Atlas 2001: Objective Analyses, Data Statistics, and Figures, CD-ROM Documentation, National Oceanographic Data Center, edited by: Levitus S., Silver Spring, MD, 17 pp. 2002.

Conte, M. H., Sicre, M. A., Rühlemann, C., Weber, J. C., Schulte, S., Schulz-Bull, D., and Blanz, T.: Global temperature calibration of the alkenone unsaturation index $\left(U_{37}^{k}\right)$ in surface doi:10.1029/2005GC001054, 2006.

BGD

7, 545-564, 2010

\section{Alkenone-based temperature patterns along the eastern South Pacific}

J. A. Placencia et al.

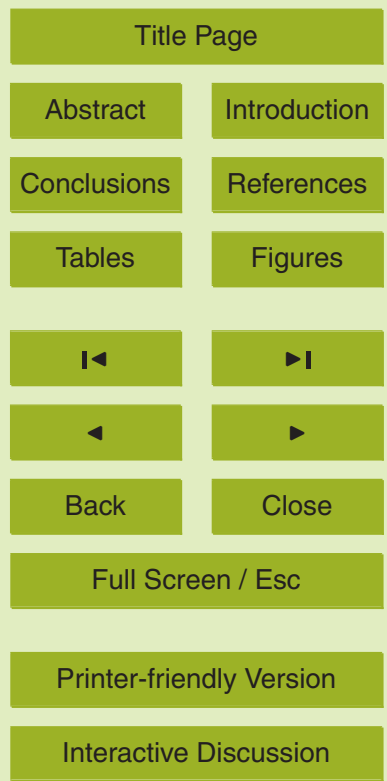


Dandonneau, Y., Vega, A., Loisel, H., du Penhoat, Y., and Menkes, C.: Oceanic Rossby waves acting as a "hay rake" for ecosystem floating by-products, Science, 302, 1548-1551, 2003.

Dávila, P., Figueroa, D., and Müller, E.: Freshwater input into the coastal ocean and its relation with the salinity distribution off austral Chile $\left(35^{\circ}-55^{\circ} \mathrm{S}\right)$, Cont. Shelf Res., 22, 521-534, 52002

De Pol-Holz, R., Robinson, R. S., Hebbeln, D., Sigman, D. M., and Ulloa, O.: Controls on sedimentary N isotopes along the Chile margin, Deep-Sea Res. II, 56, 1042-1054, 2009.

González, H. E., Menschel, E., Aparicio, C., and Barría, C.: Spatial and temporal variability of microplankton and detritus, and their export to the shelf sediments in the upwelling area off

10 Concepción, Chile ( 36 ${ }^{\circ}$ S), during 2002-2005, Progr. Oceanogr., 75, 435-451, 2007.

Harada, N., Sato, M., Shiraishi, A., and Honda, M. C.: Characteristics of alkenone distributions in suspended and sinking particles in the northwestern North Pacific, Geochim. Cosmochim. Acta, 70, 2045-2062, 2006.

Kim, J., Schneider, R. R., Hebbeln, D., Müller, P., and Wefer, G.: Last deglacial sea-surface 15 temperature evolution in the Southeast Pacific compared to climate changes on the South American continent, Quaternary Sci. Rev., 21, 1-13, 2002.

McCaffrey, M. A., Farrington, J. W., and Repeta, D.: The organic geochemistry of Perú margin surface sediments: I. A comparation of the $\mathrm{C}_{37}$ alkenone and historical El Niño records, Geochim. Cosmochim. Acta, 54, 1671-1682, 1990.

20 McGillicuddy, D. J., Anderson, L. A., Bates, N. R., Bibby, T., Buesseler, K. O., Carlson, C. A., Davis, C. S., Ewart, C., Falkowski, P. G., Goldthwait, S. A., Hansell, D. A., Jenkins, W. J., Johnson, R., Kosnyrev, V. K., Ledwell, J. R., Li, Q. P., Siegel, D. A., and Steinberg, D. K.: Eddy/Wind interactions stimulate extraordinary Mid-Ocean plankton blooms, Science, 316, 1021-1026, 2007.

Mohtadi, M., Hebbeln, D., and Marchant, M.: Upwelling and productivity along the Peru-Chile Current derived from faunal and isotopic compositions of planktic foraminifera in surface sediments, Mar. Geol., 216, 107-126, 2005.

Müller, P. J., Kirst, G., Ruhland, G., von Storch, I., and Rosell-Melé, A.: Calibration of the alkenone paleotemperature index based on core-tops from the eastern South Atlantic and 30 the global ocean $\left(60^{\circ} \mathrm{N}-60^{\circ} \mathrm{S}\right)$, Geochim. Cosmochim. Acta, 62, 1757-1772, 1998.

Muñoz, P. , Lange, C. B., Gutierrez, D., Hebbeln, D., Salamanca, M. A., Dezileau, L., Reyss, J. L., and Benninger, L. K.: Recent sedimentation and mass accumulation rates based on $210 \mathrm{~Pb}$ along the Peru-Chile continental margin, Deep-Sea Res. II, 51, 2523-2541, 2004.

BGD

7, 545-564, 2010

\section{Alkenone-based temperature patterns along the eastern South Pacific}

J. A. Placencia et al.

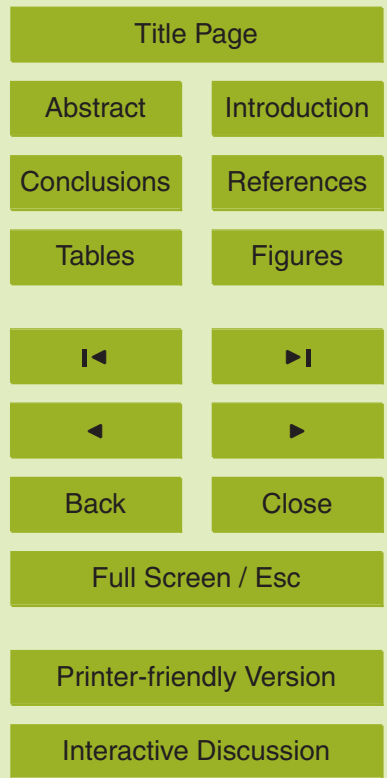


Niggemann, J.: Composition and degradation of organic matter in sediments from the PeruChile upwelling region, Ph.D. thesis, Bremen University, Germany, 206 pp., 2005.

Prahl, F. G. and Wakeham, S. G.: Calibration of unsaturation patterns in long-chain ketone compositions for paleotemperature assessment, Nature, 330, 367-369, 1987.

5 Prahl, F. G., Muehlhausen, L. A., and Lyle, M.: An organic geochemical assessment of oceanographic conditions at MANOP Site $C$ over the past 26000 years, Paleoceanography, 4, 495510, 1989.

Prahl, F. G. Muehlhausen, L. A., and Zahnle, D. L.: Further evaluation of long-chain alkenones as indicators of paleoceanographic conditions, Geochim. Cosmochim. Acta, 52, 2303-2310, 1988.

Prahl, F. G., Wolfe, G. V., and Sparrow, M. A.: Physiological impacts on alkenone paleothermometry, Paleoceanography, 18, 1-7, 2003.

Prahl, F. G., Mix, A. C., and Sparrow, M. A.: Alkenone paleothermometry: Biological lesson from sediment records off western South America, Geochim. Cosmochim. Acta, 70, 10115 117, 2006.

Rontani, J. F., Prahl, F. G., and Volkman, J. K.: Re-examination of the double bound positions in alkenones and derivatives: biosynthetic implications, J. Phycol., 42, 800-813, 2006.

Strub, P. T., Mesias, J. M., Montecino, V., Ruttlant, J., and Salinas, S.: Coastal ocean circulation off Western South America, in: The sea: the global coastal ocean, regional studies and syntheses, edited by: Robinson, A. R. and Brink, K. H., John Wiley and Sons, New York, 273-313, 1998.

Torres, R. and Ampuero, P.: Strong $\mathrm{CO}_{2}$ outgassing from high nutrient low chlorophyll coastal waters off central Chile $\left(30^{\circ} \mathrm{S}\right)$ : The role of dissolved iron, Est. Coast. Shelf Sci., 83, 126132, 2009.

BGD

$7,545-564,2010$

\section{Alkenone-based temperature patterns along the eastern South Pacific}

J. A. Placencia et al.

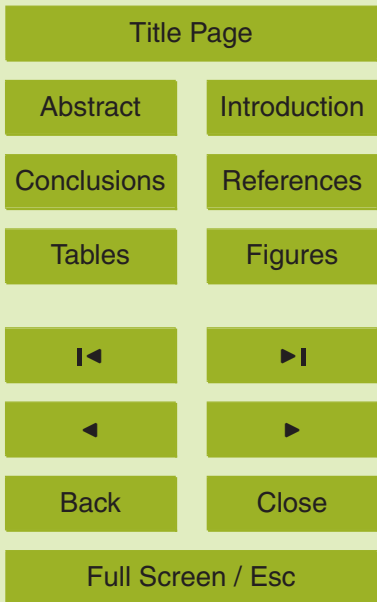

Printer-friendly Version

Interactive Discussion 
Table 1. Simple linear regression parameters for the relationship $U_{37}^{K^{\prime}}$ vs. mean annual sea surface temperature (maSST), nitrate (maNitrate), and phosphate (maPhosphate), respectively. $U_{37}^{K^{\prime}}=a+b_{1} X$, for the study area ( $n=$ number of samples; $r^{2}=$ regression coefficient).

\begin{tabular}{|c|c|c|c|c|c|c|}
\hline Relationship & $\mathbf{E q \#}$ & $\mathbf{a}$ & $b_{1}$ & $\mathbf{n}$ & $\mathbf{r}^{2}$ & Reference \\
\hline \multicolumn{7}{|l|}{ Peru-Chile margin } \\
\hline $\operatorname{maSST}$ & 1 & 0.045 & 0.031 & 83 & $0.66^{*}$ & This study \\
\hline Summer SST & 2 & 0.033 & 0.029 & 83 & $0.70^{*}$ & This study \\
\hline Winter SST & 3 & 0.110 & 0.030 & 83 & $0.71^{*}$ & This study \\
\hline \multicolumn{7}{|c|}{$\mathrm{U}_{37}^{\mathrm{K}^{\prime}}$-SST agree with annual SST variability } \\
\hline $\operatorname{maSST}$ & 4 & 0.047 & 0.034 & 28 & $0.91^{*}$ & This study \\
\hline \multicolumn{7}{|l|}{ Upwelling area $(<50 \mathrm{~km})$} \\
\hline $\operatorname{maSST}$ & 5 & 0.017 & 0.285 & 15 & $0.18^{*}$ & This study \\
\hline maNitrate & 6 & 0.456 & 0.026 & 15 & $0.50^{*}$ & This study \\
\hline maPhosphate & 7 & 0.316 & 0.316 & 15 & $0.63 *$ & This study \\
\hline \multicolumn{7}{|l|}{ Transition area $(50-200 \mathrm{~km})$} \\
\hline maSST & 8 & 0.073 & 0.028 & 32 & $0.37 *$ & This study \\
\hline maNitrate & 9 & 0.512 & -0.004 & 32 & 0.01 & This study \\
\hline maPhosphate & 10 & 0.424 & 0.111 & 32 & 0.04 & This study \\
\hline \multicolumn{7}{|l|}{ Open-ocean area $(>200 \mathrm{~km})$} \\
\hline $\operatorname{maSST}$ & 11 & 0.047 & 0.033 & 28 & $0.95^{*}$ & This study \\
\hline maNitrate & 12 & 0.633 & -0.005 & 28 & 0.01 & This study \\
\hline maPhosphate & 13 & 0.559 & 0.065 & 28 & 0.01 & This study \\
\hline \multicolumn{7}{|l|}{ Culture experiments } \\
\hline E. huxleyi (strain 55a) & 14 & 0.039 & 0.034 & 22 & 0.99 & Prahl et al. (1988) \\
\hline \multicolumn{7}{|l|}{ Core-Tops } \\
\hline Global Ocean Calibration $\left(60^{\circ} \mathrm{N}-60^{\circ} \mathrm{S}\right)$ & 15 & 0.044 & 0.033 & 370 & 0.98 & Müller et al. (1998) \\
\hline
\end{tabular}

\section{Alkenone-based temperature patterns along the eastern South Pacific}

J. A. Placencia et al.

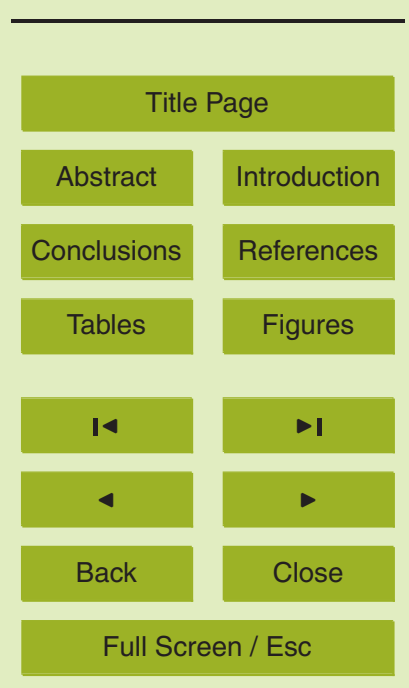

Printer-friendly Version

Interactive Discussion 


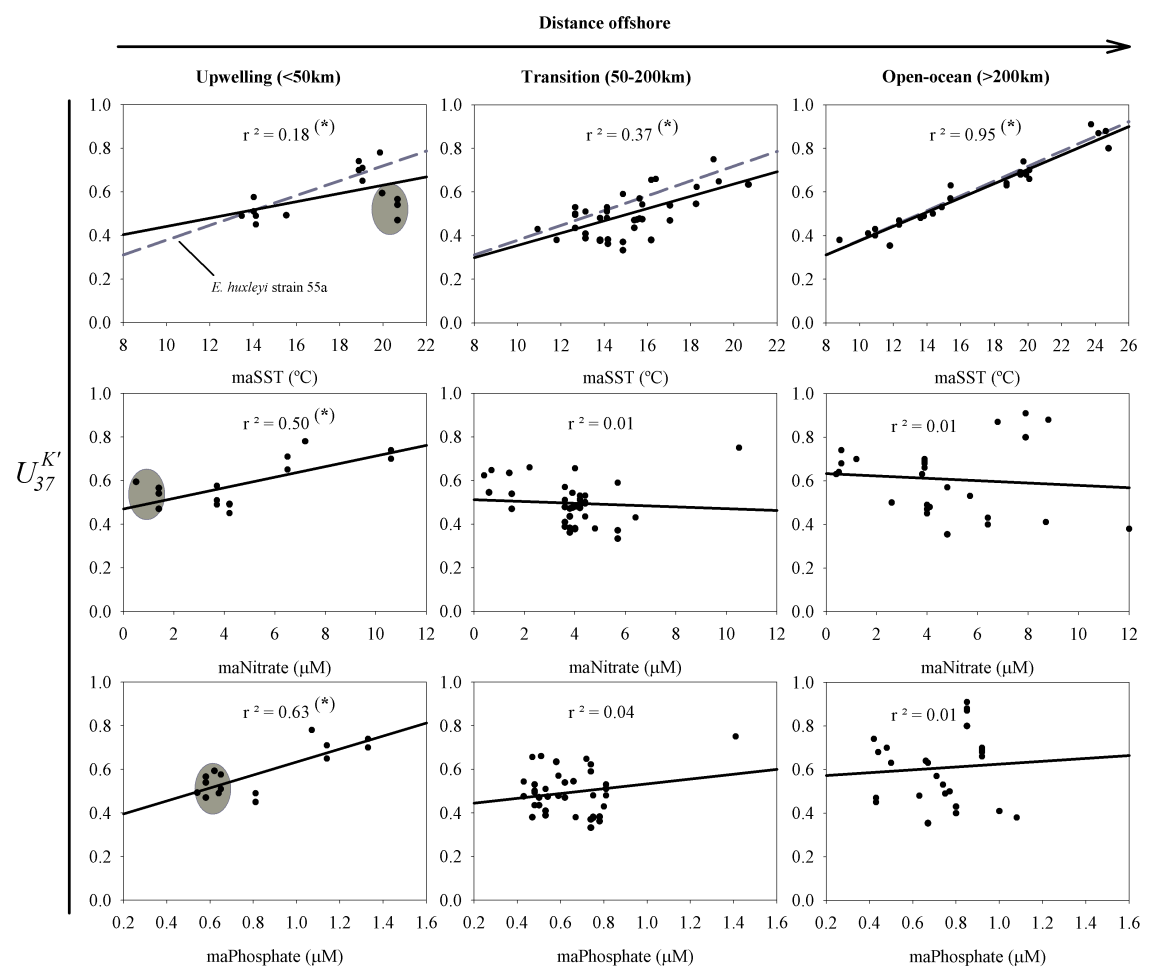

Fig. 1. Linear regressions analyses between $U_{37}^{K^{\prime}}$ and mean annual sea surface temperature, nitrate, and phosphate from coastal to open-ocean areas. Grey dotted line represents the batch culture experiment of Emiliania huxleyi strain 55a (Prahl et al., 1988). ${ }^{(*)} p<0.05$; significant regression. Grey circles denote the lowest $U_{37}^{K^{\prime}}$ from upwelling sites. Sediment samples were grouped according to latitude and offshore boundary of coastal upwelling influence. Three areas were defined: (a) coastal upwelling boundary ( $<50 \mathrm{~km}$ offshore); (b) transition area influenced by upwelling filaments and mesoscale eddies (from 50 to $200 \mathrm{~km}$ offshore); and (c) open-ocean (>200 km offshore).
BGD

$7,545-564,2010$

\section{Alkenone-based temperature patterns along the eastern South Pacific}

J. A. Placencia et al.

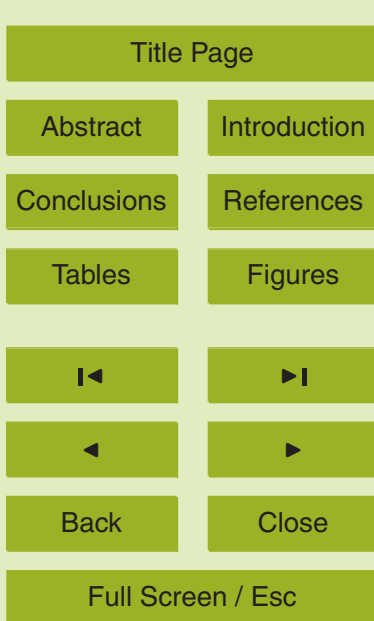

Printer-friendly Version

Interactive Discussion 
BGD

$7,545-564,2010$

\section{Alkenone-based temperature patterns along the eastern South Pacific}
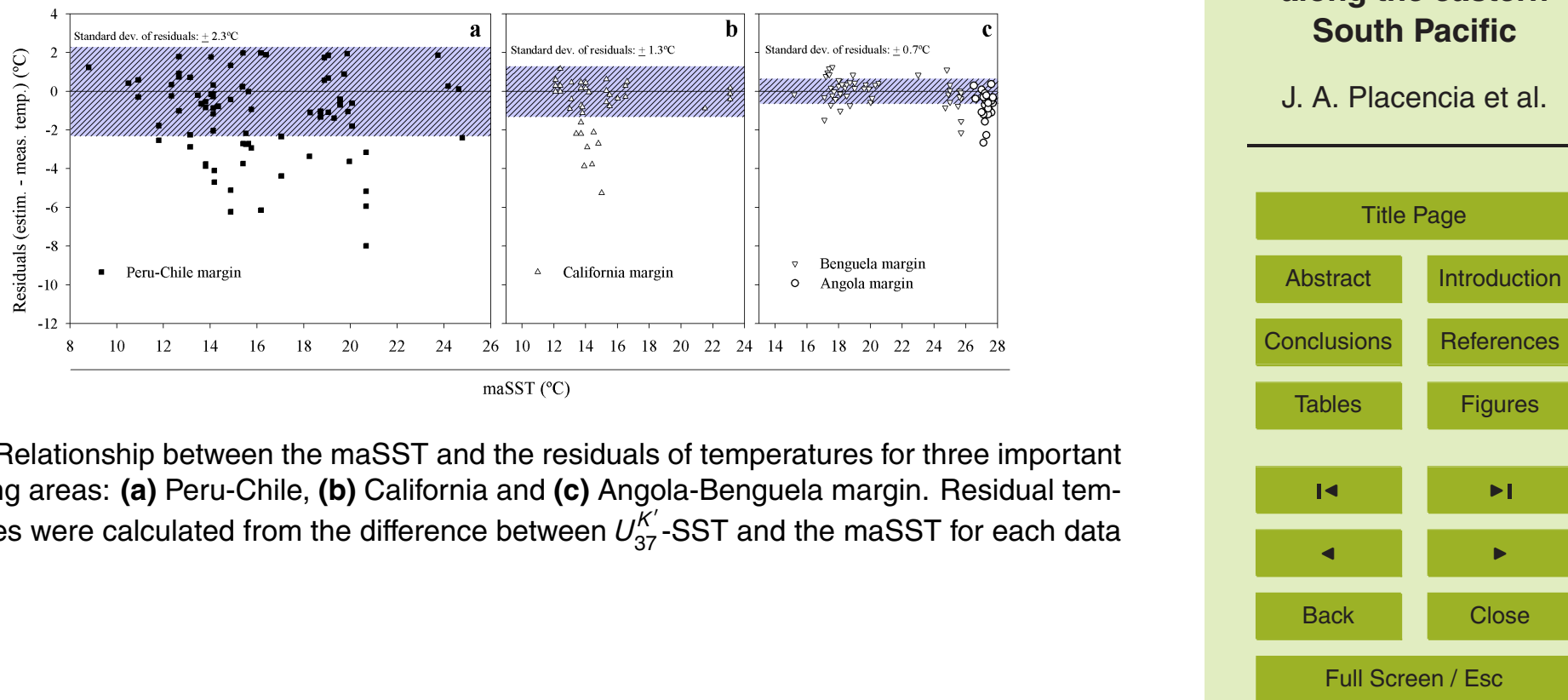

Fig. 2. Relationship between the maSST and the residuals of temperatures for three important upwelling areas: (a) Peru-Chile, (b) California and (c) Angola-Benguela margin. Residual temperatures were calculated from the difference between $U_{37}^{K^{\prime}}$-SST and the maSST for each data point.

\section{Full Screen / Esc}

Printer-friendly Version

\section{J. A. Placencia et al.}




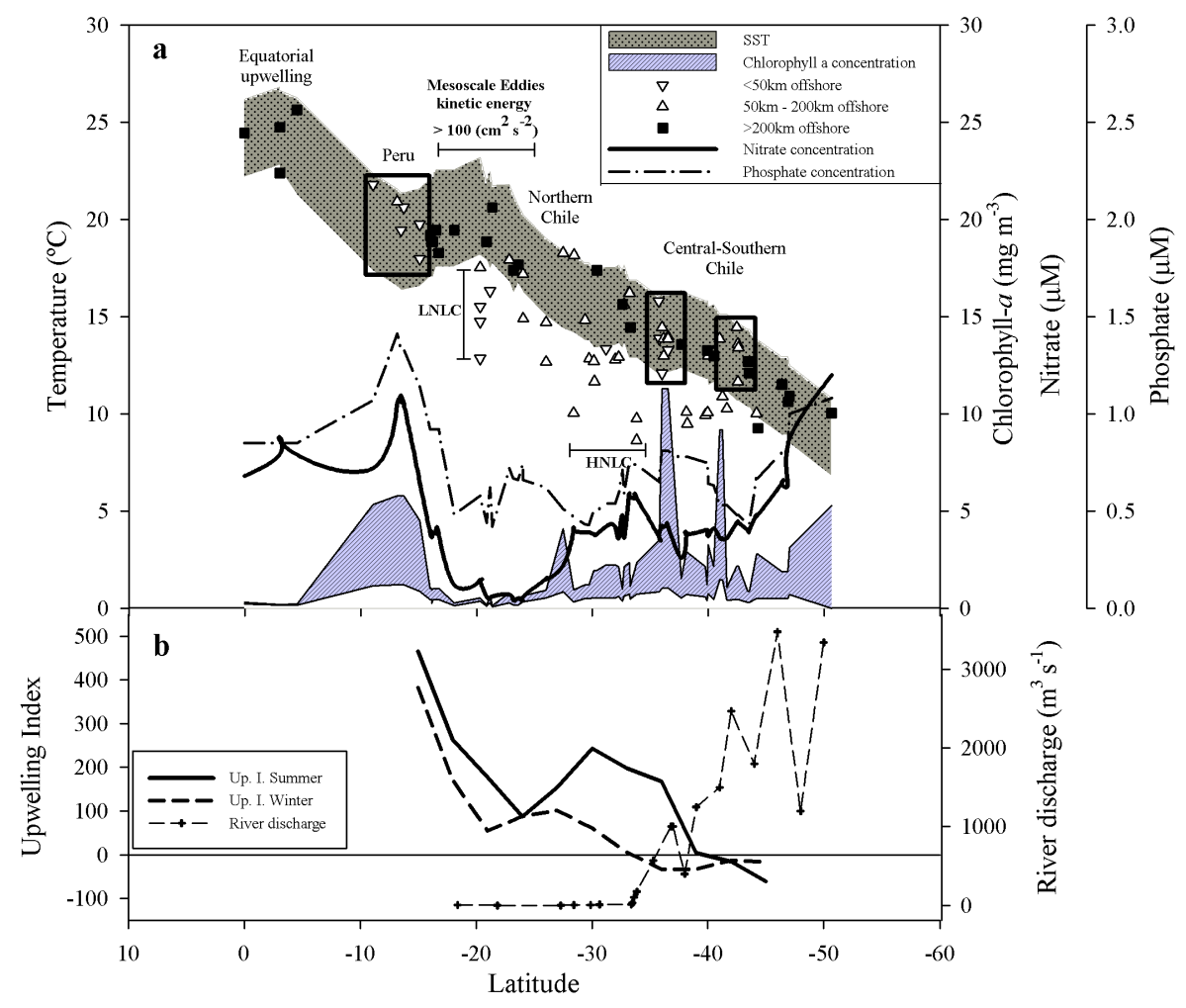

Fig. 3. Latitudinal distribution of: (a) $U_{37}^{K^{\prime}}$-SST estimated from surface sediments. The grey dotted area displays the standard deviation of the maSST $\left( \pm 2.3^{\circ} \mathrm{C}\right)$. Rectangles include upwelling points with warm $U_{37}^{K^{\prime}}$-SST. Chlorophyll-a represents the maximum/minimum values from the SeaWiFS sensor. (b) Summer/winter upwelling-index, and river discharges (Dirección General de Aguas, available at: http://www.dga.cl/, 2009; Davila et al., 2002). Upwelling-index: $\mathrm{m}^{3}$ of water upwelled/100-m coastline/s (available at: http://www.pfel.noaa.gov/, 2008).

\section{BGD}

$7,545-564,2010$

\section{Alkenone-based temperature patterns along the eastern South Pacific}

\section{J. A. Placencia et al.}

\section{Title Page}

\section{Abstract}

Conclusions

Tables

14

4

Back

\section{ntroduction}

References

Figures

$\rightarrow 1$

Close

\section{Full Screen / Esc}

Printer-friendly Version

Interactive Discussion 